and on a variety of fossil reptiles. After the War of 1914-18, he became professor of palæontology and historical geology in Munich and director of the Bavarian State Palæontological Museum; in this capacity he added very greatly to the collections, which became the most important in Continental Europe. Broili then worked on Pterodactyls and other reptiles from the Sohenhofen Slate, until, as his collection increased, he published many papers on the fauna of the Devonian Slates of Gemünden. Later, in association with Schroeder, he wrote a long series of admirable papers on the vertebrates of the Karroo system of South Africa.

Broili thus produced a very great amount of most valuable work on invertebrates as well as on all the lower classes of vertebrates. All of it is clearly written, well illustrated, and contains important discussions of relationships and other general matters. In addition he produced new editions of the famous text-book. Zittel's "Gründzuge der Paläontologie", which are still of great practical use.

Broili was most generous in his reviews of the work of younger men, and in lending to other workers the materials of which he had charge; and he enjoyed the respect and friendship of palæontologists throughout the world.

D. M. S. WATSON

\section{Mr. J. A. Gardner}

Ir was in the spring of 1911 that the Biochemical Society was founded by John Addyman Gardner, in association with other biochemists of that time. The recent and 1 noment of his death will have been received wiph Wret, but with feelings of admiration for a lef dol well spent.

Av endergetic native of Bradford, Gardner had a distnguished career at Oxford, obtaining first-class honours in the School of Natural Science in company with quite an array of distinguished Oxford chemists of his day. From Oxford he was appointed chemist to St. George's Hospital, London, a position he held until quite recently. He was for some time reader in physiological chemistry in the University of London and lecturer in organic chemistry at the London School of Medicine for Women. Always a keen research worker, his activities were for the most part conducted as biochemist at the Waller Physiological Laboratory. In this laboratory, which was at that time in the Imperial Institute at South Kensington, Gardner gathered round him a number of enthusiastic co-workers in the then rapidly spreading fleld of biochemistry.

Gardner was not alone in his desire to further the study of this subject, nor was he the only chemist to recognize the danger in those days of not keeping abreast of the knowledge of the medical aspects of chemical science. Prof. R. H. A. Plimmer, at that time reader in physiological chemistry at University College, was closely associated with Gardner in those activities, and jointly they called together a meeting which led to the foundation of the present Biochemical Society, which now has a membership roll of more than a thousand. Another pioneer was the late Prof. B. Moore, of the University of Liverpool, who with great foresight handed over to the new society the Biochemical Journal, which he was at the time publishing. The late Sir Arthur Harden and the late Prof. W. M. Bayliss gave their willing services as editors of the Journal.
Gardner was treasurer to the Society for more than twenty-two years. With great skill he nursed it through the difficult days of the First World War. $\mathrm{He}$ lived to see the Society with a world-wide membership including many eminent men of science, and a journal containing many important contributions to medical chemistry, and much of the development of our present-day knowledge of such substances as the vitamins and the sterols. It was to the lastmentioned field of study that much of Gardner's own work was directed.

The researches in which Gardner was concerned covered a wide field. He will be remembered with deep gratitude and affection by a number of coworkers for his kindly help and encouragement in their work. His researches on "The Origin and Destiny of Cholesterol in the Animal Organism", carried out in collaboration with a number of post-graduate workers, are among his best known. He clearly showed that cholesterol was widely distributed in living tissues, that it was strictly conserved and in the growing animal was not synthesized, but probably entirely derived from the phytosterol content of foods. This constant but small occurrence is perhaps explained as a source of the many essential sterols which since Gardner's earlier work have been brought to light ; for we now recognize as chemically related to cholesterol a great variety of significant biochemical substances such as the cholic acids, the D vitamins, the sex and other hormones. With the late Prof. G. Buckmaster, Gardner published a number of observations on chloroform anæsthesia. The earliest work was on the chemical constitution of some of the terpenes carried out in conjunction with the late Dr. J. E. Marsh. Gardner's more recent work was on a variety of subjects of biochemical interest.

Gardner's contribution to science, whether it be his extensive research work, his help and encouragement to so many of his co-workers in biochemistry, or whether it be his share in the establishment of an important scientific society, constitutes a magnitude of endeavour which is given to few to accomplish.

G. W. ELLIS

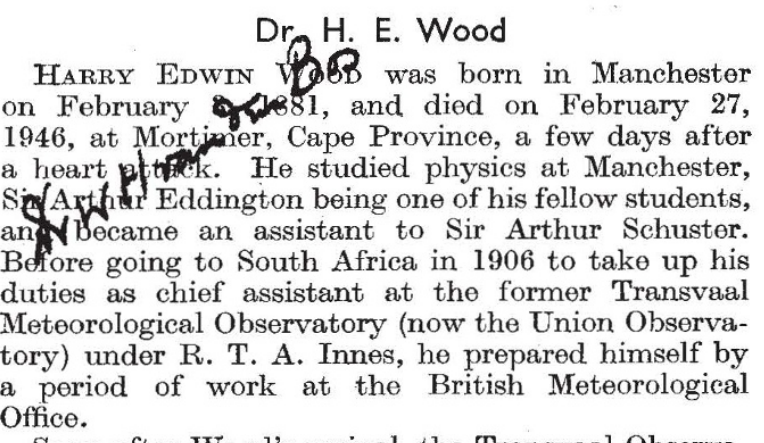

Soon after Wood's arrival, the Transvaal Observatory entered the astronomical field, Innes working with the 9 -in. visual refractor, Wood concentrating mostly on the famous Franklin Adams star camera. This remained his principal instrument until the day of his retirement in 1941. Meanwhile he had succeeded Innes as Union Astronomer on January I, 1928.

Wood was a diligent and careful observer, who used the instrument in his charge for those types of astronomical observation for which it was eminently suitable by virtue of its short focal-length, large field 